\title{
Erratum to: The conversion technology of fly ash into zeolites
}

Magdalena Wdowin • Małgorzata Franus •

Rafał Panek $\cdot$ Lidia Bandura $\cdot$ Wojciech Franus

Published online: 18 February 2015

(c) Springer-Verlag Berlin Heidelberg 2015

Erratum to: Clean Techn Environ Policy (2014)

\section{6:1217-1223}

DOI 10.1007/s10098-014-0719-6

In the original publication, a coauthor name was misspelled as Lidia Badura. The correct name of the author appears here in this erratum.

The online version of the original article can be found under doi:10.1007/s10098-014-0719-6.

M. Wdowin $(\bowtie)$

Mineral and Energy Economy Research Institute of the Polish Academy of Sciences, Wybickiego 7, 31-261 Kraków, Poland e-mail: wdowin@gmail.com

M. Franus · R. Panek $\cdot$ L. Bandura · W. Franus Lublin University of Technology, Nadbystrzycka 38D, 20-618 Lublin, Poland 